INTERNATIONAL JOURNAL OF RESEARCHES IN BIOSCIENCES, AGRICULTURE AND TECHNOLOGY (C) VISHWASHANTI MULTIPURPOSE SOCIETY (Global Peace Multipurpose Society) R. No. MH-659/13(N)

\title{
www.ijrbat.in
}

\section{LIGHT MICROSCOPIC STUDIES OF POLLEN GRAINS OF SOME ENDEMIC SPECIES OF WESTERN GHAT, NASIK}

\author{
U. G. BASARKAR \\ Professor, HPT Arts and RYK Science College, P. G. Department of Botany, Nashik 422005 (M.S.) \\ E mail - padmakarpaithankar@gmail.com
}

\section{ABSTRACT}

\begin{abstract}
Palynology, the science of pollen obtained real impetus after the discovery of the microscope. This is logical because the pollen grains are extremely tiny particles comparable to dust particles which cannot be seen by the naked eye. Pollen grain come in an infinite variety of shapes with complex surface ornamentation and occurs on almost every surface in nature. Discovery of microscope by Robert Hooke in 1665 was a landmark in the development of science particularly palynology subsequent improvement in microscopy accelerated the study of pollen grains especially finer structure of pollen wall and its varied ornamentation patterns. Light microscopic studies give information on the extreme subsurface morphology and not the extreme surface of pollen grains. In recent years the scope of pollen morphology has widened with advent of scanning electron microscopy (SEM) and with regards to unipalynous taxa, particularly the understanding of finer morphology is of fundamental of exine surface and ornamentation pattern of the pollen grains. Now a days study of pollen is an important area of research. Various pollen morphological features such as symmetry, shape, apertural pattern and exine configuration are very conservative features for the taxonomic assessment of the plant. Moreover some plants growing in the surroundings cause respiratory troubles or allergy in human beings. The pollen grains of which are responsible for allergy. The pollen grains are smallest unit of the plants, which contain so many characters of taxonomic and phylogenetic importance. The shape and size of the pollen grains, germinal furrows and the number of germ pores are important taxonomic features, which are taken into consideration in classification of plants. No survey is carried out with respect to pollen morphological studies of species endemic to western ghat (Ramshej fort) Nasik. Therefore this work will be useful for preparation of pollen calendar. By considering immense importance of pollen morphological studies in relation to taxonomy, present work is undertaken for light microscopic studies of pollen grains of some endemic species of western ghat. Total 19 types of pollen grains from different plants collected. Out of these pollen types 2 belonging to Acantheceae , 2 from Apiaceae, Asteraceae, Boraginaceae, and one from Balsaminaceae, Commelinaceae, Convolvulaceae, Cucurbitaceae, Fabaceae, Lamiaceae, Poaceae, Polygalaceae, Rubiaceae, Sterculiaceae, Verbinaceae family respectively.
\end{abstract}

Key words - Acetolysis, Endemic

\section{INTRODUCTION}

Palynology, the science of pollen obtained real impetus after the discovery of the microscope. This is logical because the pollen grains are extremely tiny particles comparable to dust particles which cannot be seen by the naked eye. Pollen grain come in an infinite variety of shapes with complex surface ornamentation and occurs on almost every surface in nature. Discovery of microscope by Robert Hooke in 1665 was a landmark in the development of science particularly palynology subsequent improvement in microscopy accelerated the study of pollen grains especially finer structure of pollen wall and its varied ornamentation patterns.

Light microscopic studies give information on the extreme subsurface morphology and not the extreme surface of pollen grains. In recent years the scope of pollen morphology has widened with advent of scanning electron microscopy (SEM) and with regards to unipalynous taxa, particularly the understanding of finer morphology is of fundamental of exine surface and ornamentation pattern of the pollen grains.

Now a days study of pollen is an important area of research. Various pollen morphological features such as symmetry, shape, apertural pattern and exine configuration are very conservative features for the taxonomic assessment of the plant. Moreover some plants growing in the surroundings cause respiratory troubles or allergy in human beings. The pollen grains of which are responsible for allergy.

The pollen grains are smallest unit of the plants, which contain so many characters of taxonomic and phylogenetic importance. The shape and size of the pollen grains, germinal furrows and the number of germ pores are important taxonomic features, which are taken into consideration in classification of plants.

Palynology does not correspond with tribal classification. However, palynology is significantly helpful at the specific and generic level within the tribes (Parveen, 2006). Pollen grains are usually radially symmetrical, isopolar, oblate-spheroidal to prolate-spheroidal rarely sub-prolate or suboblate. Sexine slightly thicker or thinner than nexine. (Quiser and Parveen, 2008). Palynology of family confirms its monotypic status (Quiser and Parveen, 2001). The similarities in structure showed interspecies relationships and reasons for them to be in the same family while the interspecific variations in structures substantiate their existence as distinct species (Mabel et. al., 2014).

Flower and pollen morphology as important repository of constant characters formed the focus of the investigation (Jayeola and Oladunjoye, 2012). The study revealed that the pollen grains were characterized by 3zonocolpate or 6-zonocolpate. Size of the pollen is variable between the genera but not among the 
species of the same genus. The surface pattern of the exine varies from fine reticulate, rough reticulate, mega-reticulate, reticulate-perforate, bireticulate- perforate or granulate, leading to 6 types of pollen grains. These variations revealed by this study imply that pollen Morphology may be of significant value sharing in solving problems in the classification (Doaigeyet.al., 2012).

No survey is carried out with respect to pollen morphological studies of species endemic to western ghat (Ramshej fort) Nasik. Therefore this work will be useful for preparation of pollen calendar.

By considering immense importance of pollen morphological studies in relation to taxonomy, present work is undertaken for light microscopic studies of pollen grains of some endemic species of western ghat.

\section{MATERIAL AND METHODS}

\section{A) Collection of pollen grains and identification of plants species}

Fresh flowers of different plant species which restricted to western ghat are collected from Ramshej fort. Plants such as Leucas longifolia ,Trichodesma zeylanicum,Impatiens balsamina, Neanotis foetida, Rostellularia crinita., Commelina sp. , Polygala persicariifolia, Heracleum grande, Cucumis setosis, Ipomoea triloba , Rostellularia procumbers, Senesio bombayensis, Echinochloa colona , Pinda concanensis, Paracaryposis sp. , Helicteres isora, Clerodendrum seratum, Indigofera glandulosa, Tithonia divirsifolia were collected and pollen morphology was studied by acetolysis method (Erdtman, 1943).

\section{B ) Preparation of glycerin jelly}

Pollen from the known plant was shaken on to a microscope slide, or the anthers were placed on a slide, and a drop of ether is added to disperse the pollen. Any visible particles that are larger than the pollen grains was removed. Drops of ether were then carefully run over the pollen from a pipette. This will dissolve any oil in the pollen and carry it to one side where it can wiped off or where the solution can be absorbed by the tissue. Then two drops, one of warmed, stained jelly and another of unstained jelly, were placed on the pollen by means of a glass rod. A cover slip is carefully positioned on top, one edge lowered first to avoid trapping air bubbles. The slide was left on a warm plate for about ten minutes. The jelly should be just sufficient to fill the space under the cover slip

Glycerine jelly was prepared by dissolving $7 \mathrm{gms}$ of gelatin in $42 \mathrm{ml}$ of cold distilled water. $50 \mathrm{ml}$ of glycerine is added, warmed gently, and stirred until it is dissolved. $0.5 \mathrm{gms}$ of phenol is added to prevent the growth of mould. To prepare the stained glycerine jelly, $0.1 \mathrm{gms}$ of basic fuchsin is dissolved in $10 \mathrm{ml}$ of alcohol (methylated spirit). This stain was then added drop-by-drop to the glycerine jelly until a clear pink color is produced.

A few hours later, when the jelly has finally set, any surplus should be cleaned off with water. The cover slip then sealed along the edges with clear nail varnish or paraffin wax. Thus treated, the slides will last for many years.

\section{C) Pollen preparation by Acetolysis method}

P.K.K Nair (1960) suggested a modification of the "Acetolysis method" of Erdtman (1943) This methodhelp in the comparative study of acetolysed and unacetolysed pollen grains and also helps in understanding the effect of acetolysis on pollen grains. A brief schedule of Nair's method is under mentioned.

\section{a) Pre - treatment and staining}

The pollen material fixed (fresh or dry anthers, flower or spike etc.) in $70 \%$ alcohol in glass vials for at least 24 hours, if dry and at least for one hour, if fresh.The material was transferred with alcohol in a centrifuge tube and crushed with a glass rod.It was then passed through a brass metal sieve having at least 48 meshes per sq. inch and collected it in a centrifuge tube 'A'. From centrifuge tube ' $A$ ' transferred one half of the dispersion to another centrifuge tube ' $\mathrm{B}$ '. Content of tube ' $\mathrm{A}$ ' was centrifuged and decanted the alcohol and added about 2 drops of safranin (5\%in water) and left for 5-10 min. Stained sediment with $70 \%$ alcohol, centrifuged, decanted off the water, washed with water, washes at least twice or thrice by centrifuging till it became colorless. $2 \mathrm{ml}$ of dilute glycerin (50\% water) added and kept this centrifuged tube ' $A$ ' in the rack.

\section{b) Acetolysis}

The tube marked ' $\mathrm{B}$ ' centrifuged and decanted off the alcohol. About $5 \mathrm{ml}$ glacial acetic acid added, centrifuged and decanted off the acetic acid. About $6 \mathrm{ml}$ of acetolysis mixture (acetic anhydride and concentrated sulphuric acid in a 9:1) added over the pollen grains in the tube 'B' and placed in the water bath and heated the water at $100^{\circ} \mathrm{c}$. When the water started boiling stopped the flame and the centrifuge tube ' $\mathrm{B}$ ' kept in water for 3-5 min. Tube ' $\mathrm{B}$ ' centrifuged and decanted off the acetolysis mixture. About $10 \mathrm{ml}$ of glacial acetic acid added in sediment in tube 'B', centrifuged and decanted the acid. Water added once or twice, centrifuged it and decanted off the water dispersed the sample in the water. One half of this dispersion transferred to a centrifuge tube marked ' $\mathrm{C}$ ' and kept the centrifuge tube ' $\mathrm{B}$ ' along with centrifuge tube ' $\mathrm{A}$ '.

\section{c) Chlorination or Oxidation}

Contents of centrifuge tube 'C', taken and centrifuged and decanted off the water. About $5 \mathrm{ml}$ glacial acetic acid added followed by 2-4 drops of saturated solution of sodium chloride or potassium chloride in the water and then added 1drop of conc. hydrochloric acid. Washed about $5 \mathrm{~min}$. centrifuged and decanted. Then washed with water once or twice and decanted the water. Few drops of methyl green added on sediment and waited for about 5 minute. Washed the sediment with water twice or thrice till the water became colorless and centrifuged every time. About $2 \mathrm{ml}$ of dilute 
glycerin added in this tube ' $\mathrm{C}$ ' and put it along with tube 'A' and ' $B$ ' in rack. Waited for about 5 minute.

\section{d) Mounting}

The pollen grains from centrifuge tube 'A 'transfer to ' $\mathrm{B}$ ' and then ' $\mathrm{B}$ ' to tube ' $\mathrm{C}$ ' centrifuged the mixture of tube ' $A$ ', ' $B$ ' and ' $C$ '. The pollen grains placed in the glycerin jelly then mounted with a thin cover slip. Acetolysed pollen grains are brown in color, acetolysed grain take red stain of safranin and chlorinated or oxidized grains are green in color. For different purpose of study, the preparations can be made of only safranin + stained grains 'A' or in combination with acetolysed grains 'A+B' or also along with chlorinated or oxidized ' $A+B+C$ ' as needed.

\section{RESULT AND DISCUSSION}

The present investigation deals with botanical survey of flowering plants growing in area of Ramshej fort near Nashik during the period of January - December 2016.

Fresh flowers from different plants from Ramshej fort collected. Collected pollen grains treated by acetolysis technique and observed under light microscope for pollen morphological studies. The purpose of this survey work was to collect the pollen materials from different plants growing in the field and study of different pollen parameters such as shape, size, colpi and exine ornamentation.

Total 19 types of pollen grains from different plants collected which are tabulated in Table - 1 and Photoplates I - II. Out of these pollen types 2 belonging to Acantheceae, 2 from Apiaceae, Asteraceae, Boraginaceae, and one from Balsaminaceae, Commelinaceae, Convolvulaceae, Cucurbitaceae, Fabaceae, Lamiaceae, Poaceae, Polygalaceae, Rubiaceae, Sterculiaceae, Verbinaceae family respectively.

Various characters have been used for the classification of the genus, including anther and pollen morphology.Terminologies have been used as per Erdtman 1960. When looking at relationships among species, the challenge is to identify consistentcharacters that can be used to group species together into both genera and intrageneric groups. External pollen morphology is such a character which has been used extensively in formulating classification systems in the Acanthaceae. An understanding of the pollen morphology gained from previous studies has assisted the understanding of the phylogeny of the family. The external features of pollen grains used in classifying species include size, shape, number of apertures and the sculpturing of the outside pollen wall layers (House, 2015).

Pollen of Rostellularia crinita showed 3aperturate and 3-sided, each side more or less prolate shape and also having much narrower exine, and the ectexine is about 2.5 times thicker than the endexine. The species belonging to same genera $R$. procumbers showed variation in pollen character i.e. pollens are all bilaterally flattened-elliptical, more or less prolate and 2aperturate. Pollens are almost obtusely rectangular in equatorial view (House, 2015).
Pollen morphology of Apiaceae family member also shows variation in various genera. The pollen grains of Heracleum grandeare radially symmetrical and isopolar. The outline is elliptic in the equatorial view and tri-angular in the polar view. The pollen grains are operculate and tricolporate (Amjad and Akkafi, 2012). Pollen grains of Pinda concanensis are prolate in shape,the polar perimeter is triangular, tricolporate whereas the equatorial perimeter is elliptic. The three longitudinal equatorial colpi are narrow with acute apex. The exine of the pollen were sculptured (Minareciet.al., 2011).

Earlier study carried out on the pollen morphology of Asteraceae family members. Senecio bombayensis has a prolate-spheroidal shapeor more rarely suboblate. The exine was tectate and echinate. The spines were conical, with a solid upper part with a canal or subapical cavity, and perforations in the lower part. Tithonia diversifolia pollens are polypantoporate, prolate spheroidal with thin wall and the pores are densely situated (Montes and Murray, 2015., Mabel et.al., 2014).

In the family Balsaminaceae represented by genus Impatience balsamina, pollen grains sub-isopolar, oblate rarely sub-oblate, rectangular tetracolpate, zonoaperturate, colpus short, narrow, not sunken. Colpal membrane scabrate, they are rectangular in polar view and elliptic in equatorial view (Quiser and Parveen, 2001). Trichodesma zeylanicum is the member of family Boragenaceae showed oval shape aperture show much more differences .Pollens are tricolpate in shape (Kumar and Kumar, 2016).

Commelinaceae,

Convolvulaceae, Cucurbitaceae families also showed variations in pollen characters. In Commelina $s p$. the pollen was divided into large and small pollen grains, the small having polar and equatorial lengths approximately half that of the large grains. They are reticulate at equatorial view and oval in shape. Ipomoea triloba is member of Convolvulaceae pollen are oblate, radially symmetrical, the outline circular, pantoporate, polytreme, pores are equidistantly distributed, tetragonal area formed by the spines, sculpturing is echinate, spines are slender, long and blunt at the ends. Cucumis setosis, Cucurbitaceae member pollen grains are tricolporate, oblate spheroidal in shape. Aperture is colpus long sunken with acute ends. In exine sexine is thinner than nexine (Davis and Hrycan , 2005.,Jayeola and Oladunjoye, 2012., Parveen and Quiser, 2008).

Pollen grains of Indigofera glandulosa are monads, medium in size prolate spheroidal in shape, triangular in polar view, 3 - colpor(oid)ate, auriculae-like structure present near aperture. Exinesculptures reticulate in the both species, nexine thicker than sexine. They are belonging to Fabaceae family. Leucasalbais the member of 
Lamiaceae family have spheroidal pollens and tectum surface is rough reticulate.Pollens are tricolpate (Sarwaret.al., 2013).

Echinochloa colona refer to family Poaceae, it shows spheroidal shape pollen grains. they are monoporate, operculate. They are annulate and exine is thiner than nexine. Spheroidal shape pollen grains also shown by Polygala persicariifolia which is the member of Polygalaceae. Pollens are radially symmetrical ,circular and oblate and also show number of colpi present on the surface (Parveen, 2006., Chantaranothai, 2009).

Pollen are oblate to prolate, spheroidal or rarely sub oblate. colpi are slightly or prominently suncken in wall. These all characters are of Neanotis phoetida which belong to family Rubiaceae (Block and Robbrencht, 1998).

Another genus Helictere isorabelong to family Sterculliaceae. Pollen of this genera are 34 zonoporate, pore are circular. Shape is subtriangular to oblate. Nexine is thinner than sexine and dentate near the pores (Sharma, 1967).

Verbinaceae shows variation in the pollen morphology of various genera. Clerodendru mseratum is genus, pollen of this are tricolporate. Shape is subprolate or prolate. Aperture is ectocolpus long narrow with acute end. Exine have sexine thinner than nexine. Tectum is very finely reticulated with spinules widely distributed (Parveen and Quiser, 2007).

Thus the taxonomic assessment of the species investigated is possible considering the pollen parameters. However, the data from other field of study like cytological, serological, biochemical and immunological might strengthen this taxonomic assessment of the species. The present study is useful in the preparation of a complete pollen calendar in different seasons of the area under investigation. A pollen calendar is useful for classification, taxonomical studies of plants as well as for allergy clinics. Plant pollen is one of the most common causes of seasonal allergic disease worldwide. This data will be useful for production of anti allergical compounds against such diseases.

The study of pollen biology has direct relevance in forestry, agriculture, plant breeding and biotechnology. This data also contribute to better understanding of the taxonomy and also phylogeny of these genera in future.The species studied have some common features which support their classification as members of a family and also some features which are useful tools in delimiting the different species as distinct species.

Diversity in pollen morphology has made such studies as valuable taxonomic tool. This study will help to resolve apparent taxonomic problems in the small genus and also has proved useful in dealing critical and disputed taxonomic problems. Pollen characters could provide additional information to improve the identification of poorly known but taxonomically and environmentally important angiosperm families.

The pollen shape of all species studied was mostly circular in polar view and oblatespheroidal in equatorial view, but subprolate, suboblate, prolate or prolate spheroidal, ovate shapes can also be found in a few species. Two pollen groups can be established on the basis of the polar type and pollen symmetry. It is difficult to delimit the species on the basis of pollen characters, namely, size, colpi length, exine thickness and exine ornamentation.

Morphological characteristics of pollen grains also can be useful characters in studies of plant taxonomy because many pollen traits are influenced by the strong selective forces involved in various reproductive processes, including pollination, dispersal, and germination. Number of colpi on pollen grains has been a useful tool in tracing evolutionary relationship among the species studied. The advanced dicotyledons have more colpi than the primitive ones, with either a colpus (monocolpate) or none at all (acolpate).

The use of pollen morphology as a taxonomic character is challenging and pollen characteristics must be considered in concern with other characteristics in evolutionary reconstructions.

Palynology is significantly helpful at the generic and specific level within the tribe. Pollen morphology also confirms stenopalynous nature of the families.

The similarities in their structure showed interspecies relationships and the reason for them to be in the same genus, while the differences in their flower and pollen structures tell about their existence as a distinct species.

In the present study most of the collected plants are endemic to Western Ghats and very meager literature is available on pollen morphology.

Therefore emphasis has been given to study pollen characters in detail by well known acetolysis method given by Erdtman in 1960 . This data will be helpful for academicians as well as researchers and scientists.

\section{REFERENCES}

Amjad, L. and H. Akkafi. 2012. Pollen structure of Kelussiaodoratisima( Umbelliferae) from Iran. Islamic azad university, Iran., (3): 2229-5518. Block, P. d. and E. Robbrecht. 1998. Pollen morphology of Pavetteae (Rubiaceae, Ixoroideae) and its taxonomic significance. Grana., 37: 260275.

Chantaranothai, P., P. Krachai and N. Piwpuan, 2009. Pollen characteristics of Polygala, Salmonia and Xanthophyllum (Polygalaceae) in Thailand. KhonKaen University, Thailand., 9(1): 27-34.

Davis, A. and W. Hrycan. 2005. Comparative structure and Pollen production of the stamens and pollinator- deceptive staminodes of Commelinacoelestis and C. dianthifolia 
(Commelinaceae). University of Saskatchewan, Canada., 95: 1113-1130.

Doaigey, A., A. Alfarhan, A. Milagy, J. Tomas, M. El- Zaidy,. Pollen morphology of certain species of the Family Laminaceae in Saudi Arabia. King saud university, Saudi Arabia. ISSN 1028-2092.

Erdtman, G. 1943. An introduction to pollen analysis, Waltham mass, Chronica Botanica Co. :175 - 179 .

House, A.V. 2015. Systematic applications of pollen grain morphology and development in the Acanthaceae. University of Witwatersrand, Johannesburg.

Jayeola, A. and O. Olandunjoye. 2012. Systematic studies in some Ipomoea linn. species using pollen and flower morphology. University of lbadan, Nigeria.,(2): 177-187

Kumar, A. and B. Kumar. 2016. Biosystematic studies in Heliotropiumindicum, Trichodesmaindicum and T. zeylanicum of Boraginaceae. Magadh university, India., 5(4): 720-729.

Mabel,A.F., A.A. Johnson and O.O. Temitope. 2014. Pollen grain morphology of some selected species of Asteraceae in South western Nigeria. Obafemi awolowo University, Nigeria., 17-23: 2231-5101.

Minareci, E., F. Mungan, K. Yildiz and M. Kilic. 2011. A palynological study of genus Smyrnium (Umbelliferae) from Turkey. Celal Bayar University, Turkey., 5(6): 997-1003.
Montes, B. and M. G. Murray. 2015. Pollen morphology of Seneciobergii (Asteraceae), with special attention to the mesoaperture. Universidad national del sur. Bahia Blanca, Argentina., 84: 201-208.

Nair, P. K. K. 1960. A modification in the method of pollen preparation. J. sci. Industry. Res.19(1): $26-27$

Parveen, A. 2006. A contribution to the pollen morphology of Family Graminaceae. University of Karachi, Pakistan. 1(2): 60-65.

Parveen, A. and M. Qaiser. 2007. Pollen flora of Pakistan - LIII. Vebinaceae. University of Karachi, Pakistan.,Pak.J.Bot.,39(3): 663-669.

Quiser, M. and A. Parveen. 2001. Pollen flora of Pakistan - XXVI. Balsaminaceae. University of Karachi, Pakistan., 40: 35-38.

Quiser, M. and A. Parveen. 2008. Pollen flora of Pakistan - LVI. Cucurbitaceae. University of Karachi, Pakistan., 40(1): 9-16.

Sarwar, A., S. Jahan and M. Alifakir, 2013. Phenology, floral morphology and seed yield in Indigoferatithonia L. and I. suffruticosa Mill. Bangladesh agricultural university, Bangladesh., 42(2): 231-237.

Sharma, B. D. 1967. Studies of Indian pollen grains inrelation to plant taxonomy Sterculiaceae. Botanical survey of India, India., vol 35: B, No. 4.

$\mathrm{k}, 391$.

Table 1:- Pollen description of studied plants

\begin{tabular}{|c|c|c|c|c|}
\hline $\begin{array}{l}\text { Sr. } \\
\text { No. }\end{array}$ & Family & $\begin{array}{c}\text { Name of the } \\
\text { Plant }\end{array}$ & Pollen grain characters & $\begin{array}{l}\text { Dimension } \\
\text { (um) }\end{array}$ \\
\hline \multirow[t]{2}{*}{1.} & \multirow[t]{2}{*}{ Acantheceae } & $\begin{array}{l}\text { A)Rostellularia } \\
\text { crinita }\end{array}$ & $\begin{array}{l}\text { 1. Pollen grains have } 3 \text {-aperture and 3-side, each side } \\
\text { more or less prolate in shape. } \\
\text { 2. The majority of the variati occurs internally in the } \\
\text { mesocolpium. } \\
\text { 3. Pollen has a much narrower exine, and the ectexine } \\
\text { is about } 2.5 \text { times thicker than the endexine. }\end{array}$ & $7 \times 5$ \\
\hline & & $\begin{array}{l}\text { B)Rostellularia } \\
\text { Procumbers }\end{array}$ & $\begin{array}{l}\text { 1. Pollens are bilaterally flattened-elliptical, more or } \\
\text { less prolate and } 2 \text { aperturate. } \\
\text { 2. They are almost obtusely rectangular in equatorial } \\
\text { view }\end{array}$ & $10 \times 8$ \\
\hline \multirow[t]{2}{*}{2.} & \multirow[t]{2}{*}{ Apiaceae } & $\begin{array}{l}\text { A)Heracleum } \\
\text { grande }\end{array}$ & $\begin{array}{l}\text { 1. The pollen grains are radially symmetrical and } \\
\text { isopolar. } \\
\text { 2. The pollen grains of studied species were prolate, } \\
\text { tricol-porate, exine sculptur-ing was rugulate, size } \\
\text { is medium. }\end{array}$ & $8 \times 5$ \\
\hline & & $\begin{array}{l}\text { B) Pinda } \\
\text { concanensis }\end{array}$ & $\begin{array}{l}\text { 1. Pollens are prolate in shape; thepolar perimeter is } \\
\text { triangular, tricolporate. } \\
\text { 2. The three longitudinal equatorial colpi are narrow } \\
\text { with acute apexes. The exine sculpturing. }\end{array}$ & $10 \times 6$ \\
\hline \multirow[t]{3}{*}{3.} & \multirow[t]{3}{*}{ Asteraceae } & $\begin{array}{l}\text { A)Senecio } \\
\text { bombayensis }\end{array}$ & $\begin{array}{l}\text { 1. It has a prolate-spheroidal shapeor more rarely } \\
\text { suboblate. } \\
\text { 2. The exine was tectate and echinate. } \\
\text { 3. The spines were conical. }\end{array}$ & Contd. \\
\hline & & & & $8^{*}$ \\
\hline & & $\begin{array}{l}\text { B)Tithonia } \\
\text { diversifolia }\end{array}$ & $\begin{array}{l}\text { 1. Pollens are polypantoporat, triprorate Spheroidal } \\
\text { and are generally medium. } \\
\text { 2. Pollens are thin wall and the pores are densely } \\
\text { situated. }\end{array}$ & $10 *$ \\
\hline 4. & Balsaminaceae & $\begin{array}{l}\text { A)Impatiens } \\
\text { balsamina }\end{array}$ & $\begin{array}{l}\text { 1. Pollen grains of this genus are oblate or } \\
\text { suboblate.4-colpate, rectangular,. } \\
\text { 2. Colpi short with reticulate tectum. }\end{array}$ & $13 \times 5$ \\
\hline
\end{tabular}




\begin{tabular}{|c|c|c|c|c|}
\hline \multirow[t]{2}{*}{5} & \multirow[t]{2}{*}{ Boraginaceae } & $\begin{array}{l}\text { A)Paracaryposis } \\
\text { sp. }\end{array}$ & $\begin{array}{l}\text { 1. Pollen grains are } 3 \text { - many aperturate. } \\
\text { 2. Pollen grains are colporate. }\end{array}$ & $4 \times 1$ \\
\hline & & \begin{tabular}{|l|} 
B)Trichodesma \\
zeylanicum
\end{tabular} & $\begin{array}{l}\text { 1. Pollen grains of this are tricolpate and they are } \\
\text { oval in shape. }\end{array}$ & $8^{*}$ \\
\hline 6. & Commelinaceae & A) Commelina sp. & $\begin{array}{l}\text { 1. Large and smallpollen grains, the small having } \\
\text { polar and equatorial lengths approximately half } \\
\text { that of the large grains. }\end{array}$ & $9 \times 7$ \\
\hline 7. & Convolvulaceae & $\begin{array}{l}\text { A) } \quad \text { Ipomoea } \\
\text { triloba }\end{array}$ & $\begin{array}{l}\text { 1. Pollens are oblate, radially symmetrical, the } \\
\text { outline circular.. } \\
\text { Pantoporate polyreme. } \\
\text { 2. Pores are equidistantly distributed, tetragonal } \\
\text { area formed by the spines. }\end{array}$ & $40 *$ \\
\hline 9. & Fabaceae & $\begin{array}{l}\text { A)Indigofera } \\
\text { glandulosa }\end{array}$ & $\begin{array}{l}\text { 1. Pollen grains are monads, medium in size, prolate } \\
\text { spheroidal in shape,triangular in polar view. } \\
\text { 2. } 3 \text { colpor(oid)ate, auriculae-like structure present } \\
\text { near colpus }\end{array}$ & $10 *$ \\
\hline 10. & Lamiaceae & $\begin{array}{l}\text { A) Leucas } \\
\text { longifolia }\end{array}$ & $\begin{array}{l}\text { 1. Pollens are spheroidal in shape, tectum surface is } \\
\text { fine reticulate, copli are 6- zonocolpate. }\end{array}$ & $7 *$ \\
\hline 11. & Poaceae & $\begin{array}{l}\text { A) Echinochloa } \\
\text { Colona }\end{array}$ & $\begin{array}{l}\text { 1. Spheroidal monoporate, operculate. } \\
\text { 2. Exine thinner than nexine. }\end{array}$ & $9 *$ \\
\hline 12. & Polygalaceae & $\begin{array}{ll}\text { A) Polygala } \\
\text { persicariifolia }\end{array}$ & $\begin{array}{l}\text { 1. Pollen grains are radially symmetrical, circular and } \\
\text { oblate, spheroidal. }\end{array}$ & $10^{*}$ \\
\hline 13. & Rubiaceae & $\begin{array}{l}\text { A) Neanotis } \\
\text { foetida }\end{array}$ & $\begin{array}{l}\text { 1. Pollen grains with long, equatorial axes, oblate to } \\
\text { prolate spheroidal or more rarely suboblate. } \\
\text { 2. Circular with slightly to more prominently } \\
\text { sunken colpi . }\end{array}$ & $10 \times 6$ \\
\hline 14. & Sterculiaceae & $\begin{array}{l}\text { A) Helictere } \\
\text { isora }\end{array}$ & $\begin{array}{l}\text { 1. Pollen grains are } 3-4 \text { zonoporate, } \\
\text { 2. Pore are circular, shape is oblate to sub triangular, } \\
\text { granulate. } \\
\text { 3. Nexine thiner than sexine. }\end{array}$ & $6^{*}$ \\
\hline 15. & Verbenaceae & $\begin{array}{l}\text { A)Clerodendrum } \\
\text { seratum }\end{array}$ & $\begin{array}{l}\text { 1. Pollens are Tricolporate Shape is sub- prolate or } \\
\text { prolate. } \\
\text { 2. Apertures Ectocolpus long narrow with acute ends. } \\
\text { 3. Exine have Sexine thinner than nexine. } \\
\text { 4. Tectum reticulate-rugulate or very finely reticulate } \\
\text { with spinules widely distributed }\end{array}$ & $23 *$ \\
\hline
\end{tabular}

$*$ Diameter of pollen grains $=1 \mathrm{x} \mathrm{b}$

\section{PHOTO PLATE - I - FLOWER MORPHOLOGY}

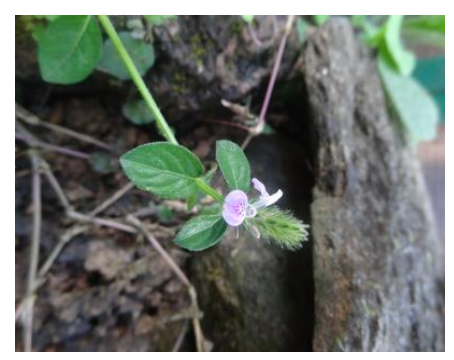

\section{Rostellularia crinita}

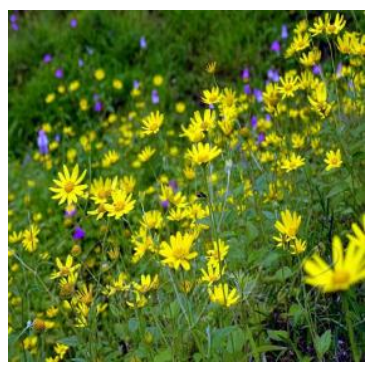

5. Senecio bombayensis

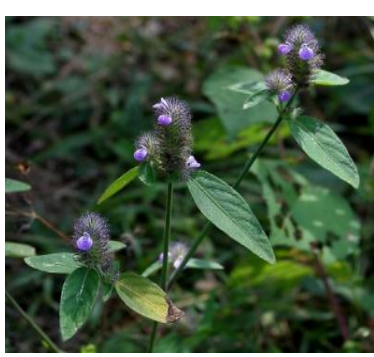

2.Rostellularia procumbers

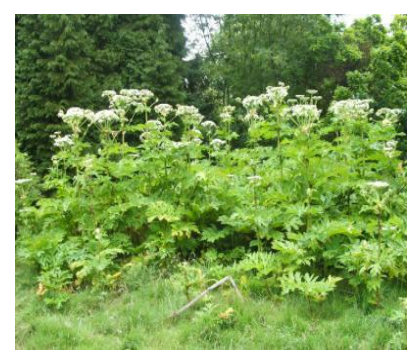

\section{Heracleum grande}

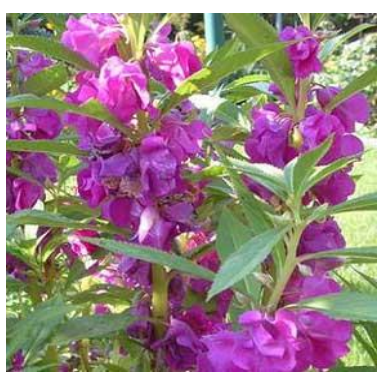

7. Impatience balsamina

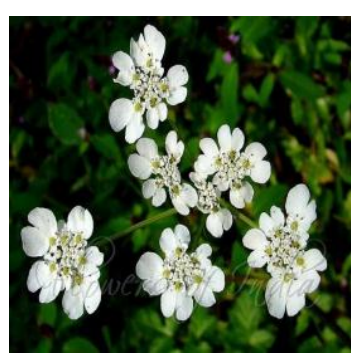

4. Pinda concanensis

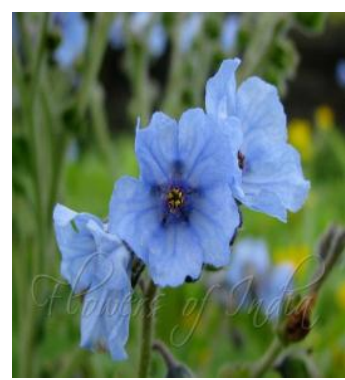

8. Paracaryposis sp. 


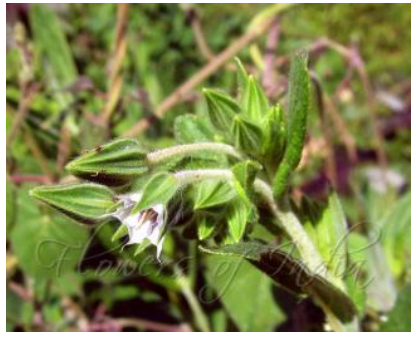

9. Trichodesma zeylanicum
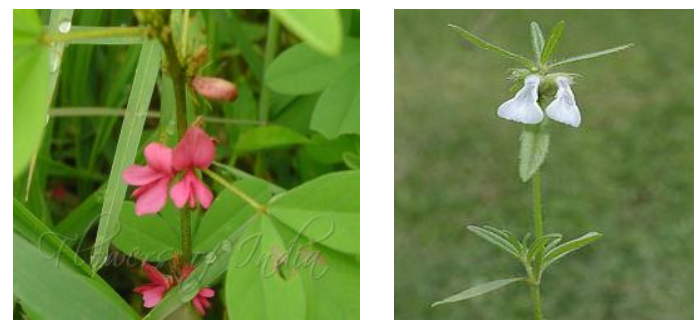

13. Indigofera glandulosa

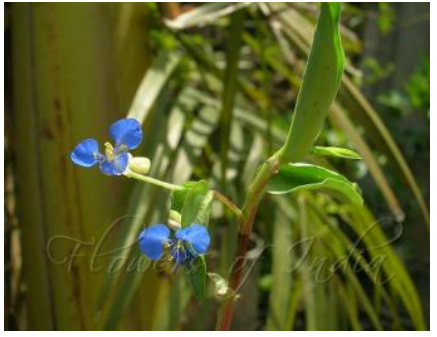

10. Commelina sp.

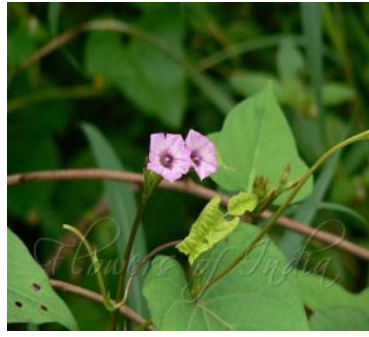

1. Ipomoea triloba

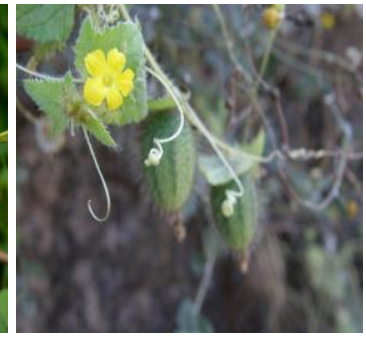

12. Cucumis setosis

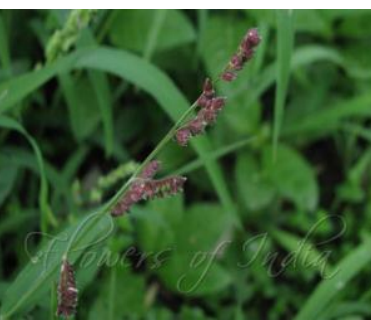

15.Echinochloa colona

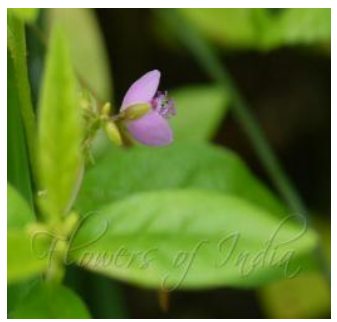

16. Polygala persicariifolia

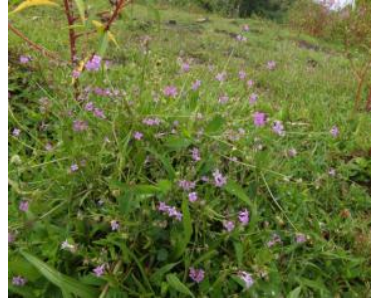

17. Neanotis foetida

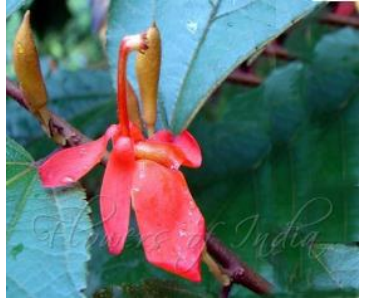

18. Helicteres isora

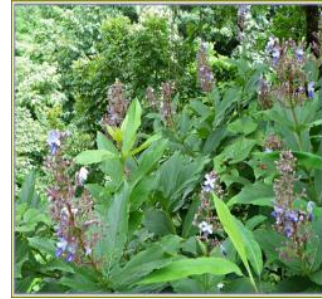

19. Clerodendrum seratum

PHOTO PLATE - II - POLLEN MORPHOLOGY
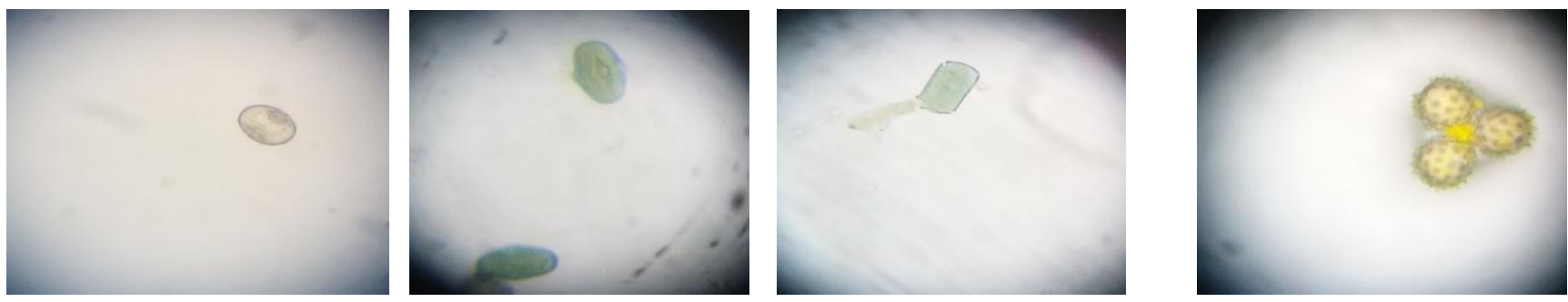

1.Rostellularia crinita

2. Pinda concanensis

3..Rostellularia procumbers

4. Senecio bombayensis
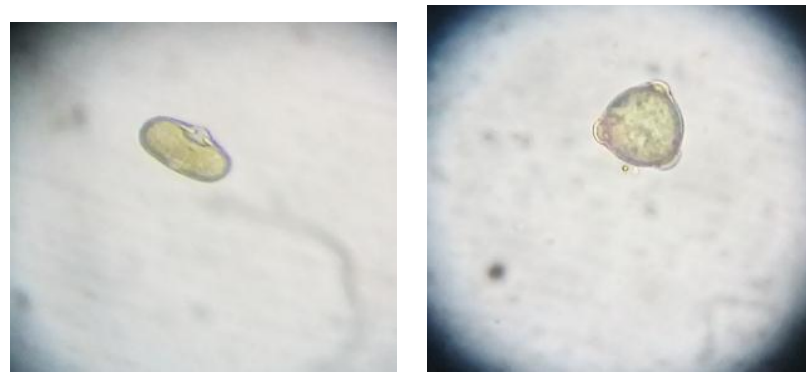

5. Heracleum grande
6.Tithonia diversifolia

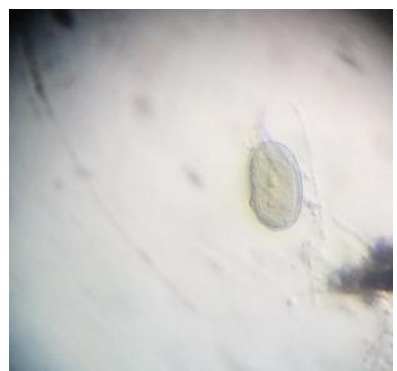

7.Impatience balsamina

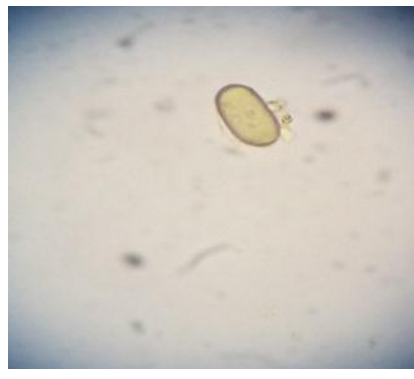

8. Commelina sp.
ת) 0
0
0 


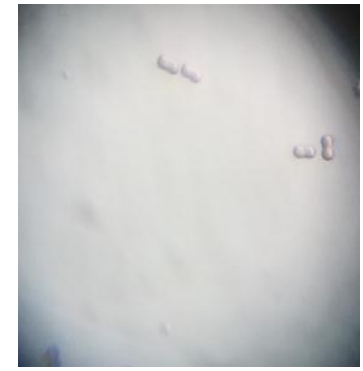

9. Paracaryposis sp.

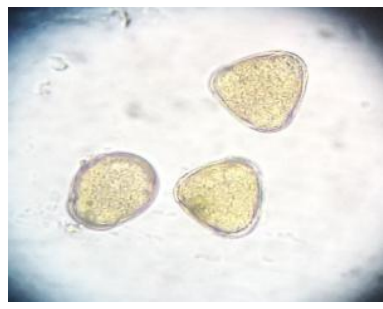

13. Indigofera glandulosa

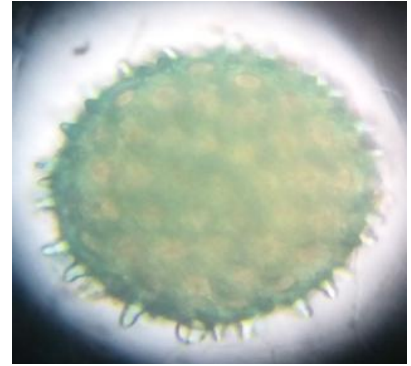

10. Ipomoea triloba

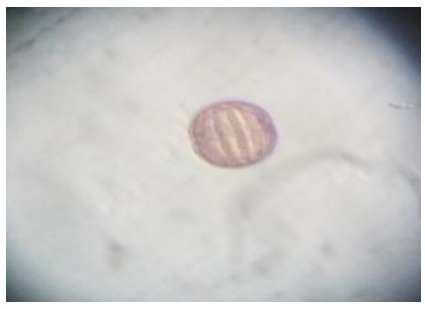

14.Polygala persicariifolia

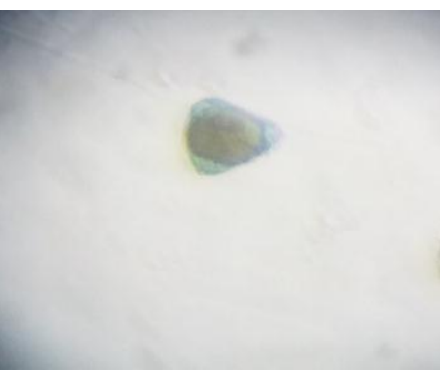

17.Echinochloa colona

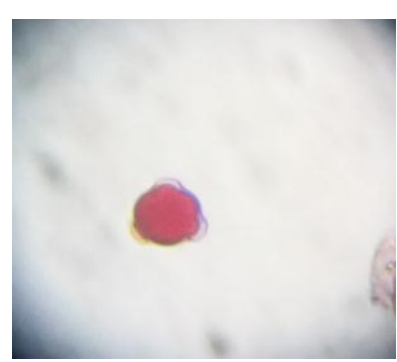

11.Trichodesma zeylanicum

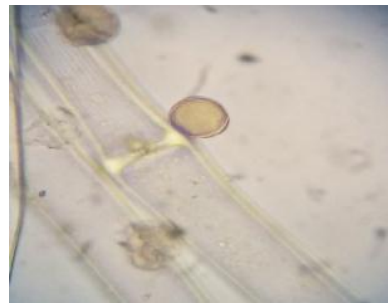

15. Leucas longifolia

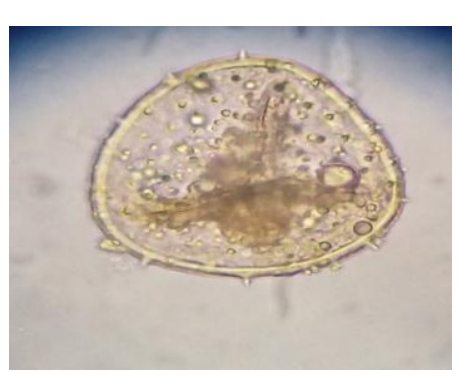

18. Clerodendrum seratum

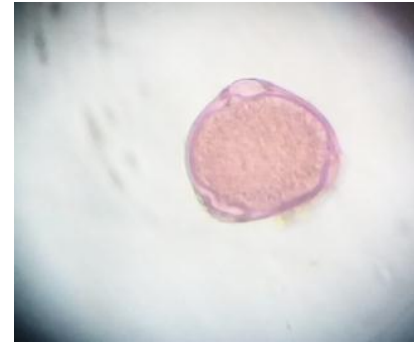

12. Cucumis setosis

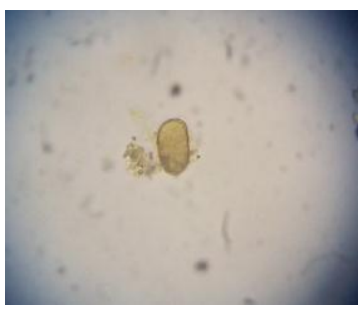

16.Neanotis foetida 